\title{
Study on the Libero's Game Patterns in Serve Take-Over in Junior Volleyball Teams II
}

\author{
Alexandru-Rares PUNI', Iulian DUMITRU²
}

\begin{abstract}
In our present paper we will try to illustrate, for the benefit of those directly involved such as players, teachers and game leaders - some aspects that, by defining new game and training concepts dedicated to juniors II, could prove essential to the progress and present development of volleyball.

Based on existing facts, we consider that our present research is necessary and modern at the same time, because of the evolution of volleyball as a sport, and due to the belief that our hypothesis has both theoretical value with consistent chances of generalization, and practical value with immediate applicability, too. Another argument would be the fact that finding adequate solutions for increasing defence efficiency could also lead to great results, since a proper defence strategy has, in most cases, a decisive influence upon the results at the end of the game.

Our present endeavour falls into the categories of volleyball theory and method, and we pledge to bring our modest contribution to the development of theoretical material useful to volleyball specialists, that could also help reinventing this particular sport discipline in our country.
\end{abstract}

Key words: volleyballs, statistics, performance, player

\section{Rezumat}

Prin rândurile de faţă vom încerca să ilustrăm celor direct interesaţi: jucători, antrenori, profesori, conducători, o serie de aspecte ce pot prin introducerea unui nou concept de joc şi pregătire la nivelul junioarelor II, bazat pe folosirea modelului şi modelării, să se constituie într-o activitate esenţială în progresul şi dezvoltarea actuală a acestui joc sportiv.

Pornind de la unele realităţi existente considerăm că cercetarea de faţă este actuală şi necesară datorită evoluţiei jocului, precum şi credinţei că ideea are o valoare teoretică cu şanse de generalizare, dar şi o valoare practică cu aplicabilitate imediată. Un alt motiv a fost acela că, găsirea unor soluţii adecvate de creştere a eficienței jocului în apărare, poate conduce la obţinerea unor rezultate deosebite, apărarea fiind de multe ori cea care influențează decisiv rezultatul unei partide.

Lucrarea de faţă face parte din teoria şi metodica jocului de volei, prin finalizarea ei vom căuta să aducem o contribuţie modestă la elaborarea unui material teoretic care să fie folositor specialiştilor din domeniu şi care prin conţinutul ei alături de alte mijloace, să poată ajuta la relansarea pe cât posibil a voleiului din țara noastră.

Cuvinte cheie: volei, statistică, performanță, jucător

\footnotetext{
${ }^{1}$ Lecturer, "Alexandru Ioan Cuza" University, Iași, Romania, Faculty of Physical Education and Sports, e-mail: punirares@yahoo.com

${ }^{2}$ Lecturer, "Alexandru Ioan Cuza" University, Iași, Romania, Faculty of Physical Education and Sports
} 


\section{Introduction}

With far too distant origins, sport was designed because of the mankind's yearning to move and to evolve, in order to keep in touch with both the outer environment and the inner self, hence the desire to compete, to be the first $[7,8]$. In time, practicing sports has become a social phenomenon of such a great importance that diminishing its scope would be unconceivable for its admirers $[1,15]$.

From the perspective of performance in sports, volleyball aims at valorising the qualities its practitioners possess, such as talent, and numerous motor, psychological and training skills displayed during competitions $[10,13]$.

The requirements of the modern volleyball game compel athletes to be exceptionally qualified in all aspects: physical, technical, theoretical and psychological, all this building upon the support of general psycho-motor skills and, in particular, of the psycho-motor skills specific to volleyball $[16,2]$.

Achieving success, as the final goal in the performance volleyball game, currently depends upon the continuous updating of the contents and forms of manifestation of both efforts and demands, on the competitive requirements, upon continuous study and research [5]. However, no investigation, research or theoretical demonstration is possible without touching the points dominated by practice itself $[17,4]$.

In this paper we will try to determine and to present, in relation to the creation of certain patterns, the possibility of translating its components into a data structure capable of emulating the model: namely, by observing and analysing the game of the player occupying the libero position, to determine a game pattern for receiving the serve and then to adequately shape an adequate presentation of the respective model (9). Determining the game patterns of the libero player when receiving the serve, at junior team level II, requires extensive knowledge of his/her game content and efficiency, as well as information regarding the direction the game progresses towards $[14,3,12]$.

\section{Research development}

The competition we based our research upon took place between October 2016 and April 2017, when we monitored 8 matches the LPS Unic Piatra Neamţ team played within the Women's Junior II National Championship.

In order to make the most accurate records and according to research requirements, we used the registration form presented below, containing the following data:

Registration card (model)

\begin{tabular}{|c|c|c|c|}
\hline Date & & & \\
\hline Game & & & \\
\hline Score & & & \\
\hline Player & & & \\
\hline Team & & & \\
\hline Personal info & $\begin{array}{l}\text { Year of } \\
\text { birth: }\end{array}$ & Hight: & Weight: \\
\hline
\end{tabular}

\begin{tabular}{|c|c|c|c|c|c|}
\hline \multirow{2}{*}{ Set } & \multicolumn{2}{|c|}{$\begin{array}{c}\text { Structure I } \\
\text { (at serve) }\end{array}$} & \multicolumn{3}{|c|}{$\begin{array}{c}\text { Structure II } \\
\text { (at receiving the serve) }\end{array}$} \\
\cline { 2 - 6 } & $\begin{array}{c}\text { Take- } \\
\text { over } \\
\text { from } \\
\text { attack }\end{array}$ & $\begin{array}{c}\text { Other } \\
\text { actions } \\
\text { (pass+a } \\
\text { ttack) }\end{array}$ & $\begin{array}{c}\text { Serve } \\
\text { take- } \\
\text { over }\end{array}$ & $\begin{array}{c}\text { Take- } \\
\text { over } \\
\text { from } \\
\text { attack }\end{array}$ & $\begin{array}{c}\text { Other actions } \\
\text { (pass+attack) }\end{array}$ \\
\hline I & & & & & \\
\hline II & & & & & \\
\hline III & & & & & \\
\hline IV & & & & & \\
\hline V & & & & & \\
\hline
\end{tabular}

The recording of each game action is done by using certain encodings that cover as accurately as possible the actions of each of the registered players, their effectiveness being marked with the following qualifiers:

- won: \#

- neutral: 0

- wrong: =

For each game action we used the following encodings:

For serve take-oveR:

$\mathrm{D}$ - for the right side of the playfield $+, 0,=$

$\mathrm{S}$ - for the left side of the playfield,+ 0 , =;

A - for other areas,+ 0 , =;

$\checkmark \quad$ For pass $+, 0,=$;

$\checkmark \quad$ For attack,+ 0 , =;

$\checkmark \quad$ For take-over from attack:

Z5 - for zone 5 and,+ 0 , =;

Z6 - for zone 6 and +, 0, =;

$\mathrm{AZ}-$ for other areas,+ 0 , $=$. 
Also, the record sheets register the positions of the libero players on the field and in the areas where the game actions took place. The players' actions were recorded for each set, at the end of the game they were added up and then, by dividing the sum to the number of sets played, resulted the set average for each game. In order to illustrate game efficiency, according to the records, we calculated for each game action the coefficient of efficiency, according to the formula designed by Professor Dan Lazarescu:

$$
\mathrm{E}=\frac{a+b * 0,50}{a+b+c}, \text { where: }
$$

$\mathrm{E}=$ coefficient of efficiency;

$\mathrm{a}=$ actions won, with maximum weight assigned (100\%)

$\mathrm{b}=$ undecided actions (neutral), with 50\% weight assigned

c = wrong actions, whose weight is null $(0 \%)$.

In order to analyse, to interpret and to highlight the results obtained from the statistical and mathematical processing of recorded information, we used graphical representations that reflect most eloquently the requests' dynamics and the efficiency of the libero players' game actions upon receiving the service [11].

\section{Results}

In the following paragraphs we will explain the patterns of each game action's content and efficiency, for both the libero player, as illustrated in Structure II (at serve), and for two of the most important game actions this player participates to (take-over from serve and from attack), in order to facilitate their analysis, to make them as clear and close to the reality of the competitive game as possible.

Regarding the content of the game actions content during the entire set, it can be said that they are distributed according to the number of executions, ranging from 13.3 (take-over from service - 84.2\%) to 0.1 (attack - representing only $0.6 \%$ ).

The action of highest importance in the libero's game is the take-over from serve, followed at great length by the take-over from attack (Figure 1). It was quite surprisingly to realize, when analysing the graphical representation of the game that the libero player's game also includes actions such as the pass and the attack, as the reality of the game demonstrates that this player must perform these game actions, too, in certain situations. These actions, despite not being specific to libero player, will therefore be trained through special executions, such as: the attacks from behind the three-meter line, the overhead pass, also from behind the threemeter line, and the raise of the ball for attack with two hands, from below [6].

The very low weight (13.3\%) of the take-over from the attack demonstrates the libero player's very low effectiveness in the second line defence, and in conclusion, the lack of adequate training targeting this specific game action for many players in this position at junior level II.

Nevertheless, it is noteworthy that the number of take-overs from attack involving the libero player is well above the average of each of the other players on the team.

We have structured our analysis on sets, in order to make a relevant comparison between the requirements and the efficiency of all actions, thus highlighting their positive and negative aspects during the game, which could lead either to their elimination, or to the further preparation of the most appropriate means of training.

When analysing the game actions in structure II, we can see the high level of content (15.8 shares / set) and the efficiency of the take-over from service ( $\mathrm{E}=$ 0.84), that is, that the actions constituting the main task of the libero player are only part of the phase I of the game and are normally played more than the other actions. The service take-over is, in this case, the action that has a particular contribution to the winning of the phase and, therefore, the way it is prepared in the context of the other actions specific to phase I (pass and attack) determines, to a great extent, winning the service and the point and, quite often, the set itself.

In Structure II, namely the take-over from attack has less weight, since this action lacks completely during the phase I and since there are only a few phases during the game where this fundamental structure is included.

These two actions, the pass and the attack, are only incidentally present in the libero player's game and only when certain actions are not properly resolved by the other members of the team. The values 
presented in this paper cannot be considered as representative for the player on this position.

In most cases, it is the libero player doing the service take-over, either by using the forearm pass or by overhead passing.

It could also be inferred that the libero player at the level of junior teams II is generally well equipped for this task, often solving more than $55 \%$ of the team's service take-overs, with a coefficient of efficiency good quite for this position, at this level.

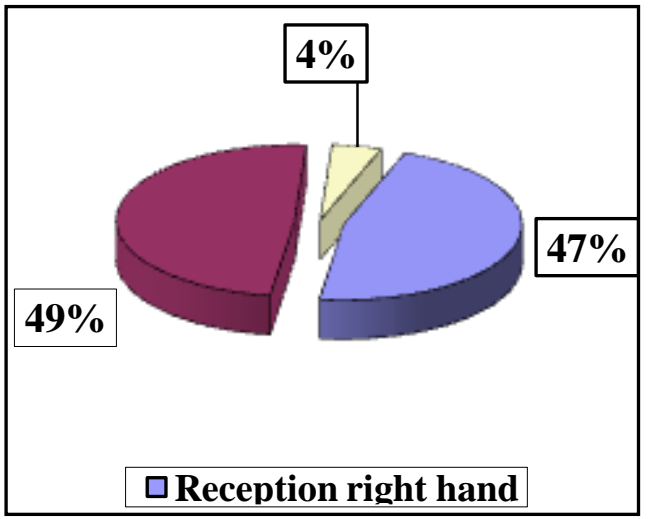

Chart no. 1 Representing the content patterns for service take-over of the libero player
Take-over from attack reveals balanced numbers in areas 5 and 6 , which are the main responsibilities of the libero player, and the take-overs from other areas have a smaller value, of only $19 \%$ of the total number of take-overs from attack, as presented in chart no. 3 .

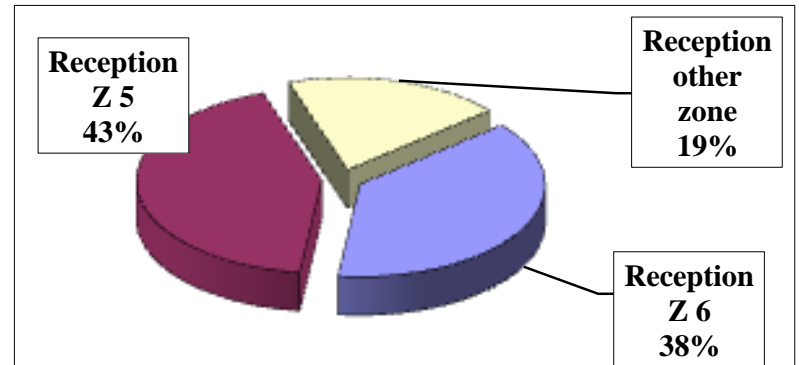

Chart no. 3 Representing the content patterns for take-over from attack of the libero player

The effectiveness of this action is relatively low, but it is representative for the libero player's game, given the number of balls recovered, as compared to the number of balls played and lost by other team players (chart 4).

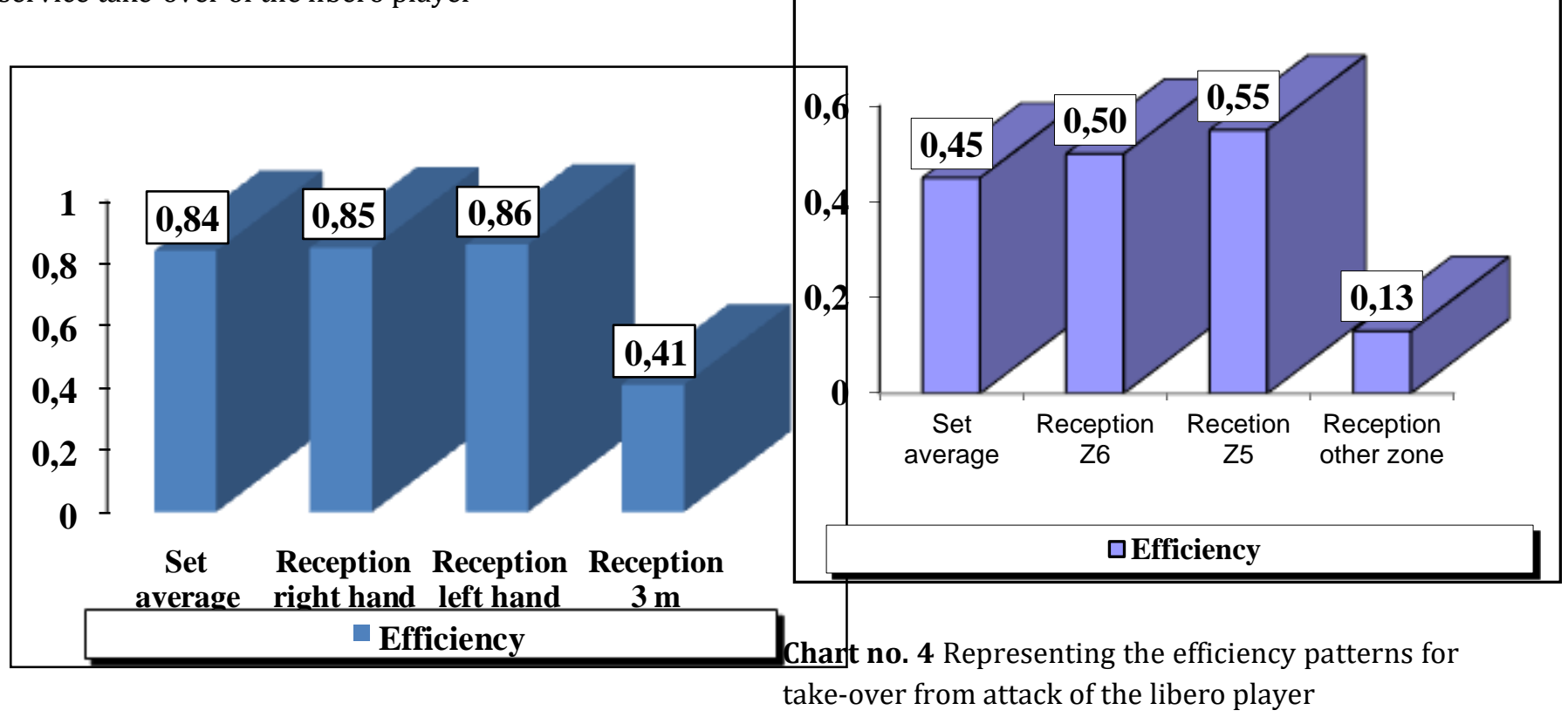

Chart no. 2 Representing the efficiency patterns for service take-over of the libero player

From chart no. 2 it can be noticed that the efficiency of the service take-over has the lowest value (0.41) when happening from line I. Service take-overs from either the right or the left side of the field are equally effective.
By analysing the data presented in graphs no. 3 and 4 , we can conclude that the take-over from attack, an action of particular importance especially in winning points, presents itself with low levels of both requirements and efficiency for this position, which reveals inappropriate and insufficient training for this action at the level of many junior II teams. 


\section{Conclusions}

As a result of data processing and interpretation, we have determined and developed a series of patterns for the game content and efficiency of the libero players in the Women's Junior II divisions, and by analysing their components we have drawn a series of conclusions of great value in practical training, such as:

$\checkmark$ Knowing the game actions' content and effectiveness for all the team players is necessary and mandatory, since it is essential to the quality of the training, according to the current performance requirements of the volleyball game.

$\checkmark$ The development of game patterns, based on its components, must rely upon the weight and efficiency of the game, therefore they will be elaborated according to the data and information provided by the official game, competition.

$\checkmark \quad$ For the libero player, the patterns and parameters regarding the game content and effectiveness must be the starting points in both game and training, since obtaining good results is often conditioned by continuously overcoming their level, a mandatory requirement if we take into account the ever increasing value of the players and the permanent progress of the game.

$\checkmark \quad$ The preparation of the specific actions of the libero player's game must follow the game situations specific to each set, each basic structure and phase, and must observe the parameters of the competitive patterns of game content and efficiency.

$\checkmark$ Despite the fact that, for achieving great results, the preparation of all game activities is mandatory, the actual situation of the Juniors II Division Championship compels us to emphasize the need to pay more attention to the take-over from serve and from attack in the training of the libero player.

$\checkmark$ Libero players in junior II teams must have a somatic, motor and technical-tactical profile according to this level, as it follows:

- be of medium height (165-170 cm);

- be equipped with speed and deftness (especially speed of reaction and movement) at an extremely high level;

- have very good acrobatic training, specific to the volleyball game;

- have a good orientation in space;

- have a pronounced sense of where the ball is;
- strike the ball correctly, including in situations when she lacks equilibrium;

- be very efficient and well prepared to takeover from serve and take-over from attack, game actions specific to this position;

- fit into the team's strategy and configuration.

With this research, we have tried to bring our contribution to the development of volleyball theory and methodology and to provide coaches with reliable information on the content and effectiveness of the game of the libero player, which are essential milestones in training the players at this level.

\section{References}

1. Bâc O., Pop N. (1995). Volei 100 de ani, Editura Daco Press, Cluj-Napoca;

2. Constantinescu P. (1986). Sisteme ierarhizate, Editura Academiei, Bucureşti;

3. Cojocaru A., Cojocaru M. (2009). Volei - teorie și practică, Editura BREN, Bucureşti;

4. Cojocaru A., Cojocaru M. (2009). Volei - antrenament şi performanță, Editura BREN, București;

5. Dragnea A. (1992). Antrenament sportiv, ANEFS, Bucureşti;

6. Dragnea A. (1992). Teoria şi metodologia antrenamentului sportiv, ANEFS, București;

7. Dragnea A. (2002). Teoria educaţiei fizice şi sportului, Editura FEST, Bucuresti;

8. Drăgan A. (2000), Volei noţiuni de bază, Editura Fundaţiei România de Mâine, Bucureşti

9. Epuran M. (1990). Modelarea conduitei sportive, Editura SportTurism, București;

10. Drăgan I. (1994). Medicina sportivă aplicată-volei, Editis, București;

11. Ghenadi V.,(1994). Volei, specializare - curs pentru studenţi, Universitatea Bacău, Bacău;

12. Ghenadi V. (1996). Volei-obiectivizarea instruirii, Editura Plumb, Bacău;

13. Ghenadi V. (1994). Model şi modelare în voleiul de performanță, Editura Plumb, Bacău;

14. Ghenadi V. (1972). Volei sub formă de joc, Editura Sport Turism, București;

15. Mârza D., Grapă F. (1998). Volei în învăţământ, Editura Plumb, Bacău;

16. Mârza D., Grapă F. (2007). Volei în învăţământ. Ediţia a II-a, Editura PIM, Iaşi;

17. Mârza D. (2006). Volei - Bazele teoretice şi metodice, Editura PIM, Iaşi;

18. Mârza D. (2006). Modelarea şi optimizarea pe baze informatice a pregătirii și competiţiei în jocul de volei, Editura PIM, Iaşi 